\title{
CREATING A MODEL OF THE FUTURE OF THE EIGHTH TECHNOLOGICAL ORDER
}

\author{
Valery Vladimirovich Glushchenko ${ }^{1 \otimes \text { (iD }}$ \\ ${ }^{1}$ Moscow Polytechnic University, Professor of the Project Activity Center, Moscow, Russia.
}
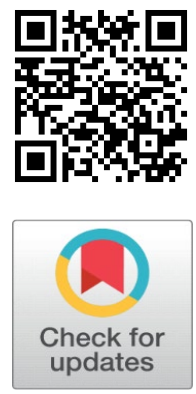

Received 01 August 2021

Accepted 15 August 2021

Published 31 August 2021

\section{CorrespondingAuthor}

Valery Vladimirovich Glushchenko, valery.v.glushchenko@gmail.com

DoI 10.29121/IJOEST.v5.i5.2021.217

Funding: This research received no specific grant from any funding agency in the public, commercial, or not-for-profit sectors.

Copyright: (C) 2021 The Author(s). This is an open access article distributed under the terms of the Creative Commons Attribution License, which permits unrestricted use, distribution, and reproduction in any medium, provided the original author and source are credited.

OPEN ACCESS

\section{ABSTRACT}

The subject of the article is a model of the future of the eighth technological order; the object of the article is the eighth technological order; the purpose of the work is to increase the efficiency of the processes of the state's entry into the eighth technological order; to achieve this goal, the following tasks are solved: the geopolitical and socio-economic roles and the results of the state's transition to the eighth technological order are described; a systematic analysis of technological orders is carried out; the image of the future eighth technological order is formed; the tasks of the state's entry policy into the eighth technological order are developed; the indicators of evaluating the effectiveness of the state's entry policy into the eighth technological order are described; the scientific methods of this article are: modeling, historical, system, comparative and logical analysis; heuristic synthesis, political science, system approach, heuristic design, expert methods, efficiency theory; The scientific novelty of the work is determined by the synthesis of the image of the future, the paradigm and policy of the state's transition to the eighth technological order, the formation of a system of indicators of the effectiveness of the state's entry into the eighth technological order.

Keywords: Modeling, State, Technological Order, Table, Policy, Analysis, System Approach, Indicator, Structure

\section{INTRODUCTION}

The relevance of this work is determined by the need to improve the effectiveness of the policy of entering states into the eighth technological order in the world economy. The task of entering the eighth technological order is also faced by other types of organizations: regions; corporations, technology platforms; clusters and firms. The process of entry of all types of organizations (the state, corporations and others) is influenced by the global systemic crisis. This crisis is closely connected with the process of forming a new technological order

The entry of all types of organizations into the eighth technological order can be called the most important problem of the world economy and society for the period up to 2040 .

The subjects of the process of transition to the eighth technological order are: global governance bodies (the World Monetary Fund, the World Bank, etc.); national governments; political parties; managers of corporations and firms, etc. 
The hypothesis of the article is the statement that the development of the paradigm and policy of the organization's entry into the eighth technological order will ensure an increase in the efficiency of the processes of formation of the eighth technological order in the world economy and society.

The purpose of the work is to increase the efficiency of the processes of the state's entry into the eighth technological order.

To achieve this goal, the following tasks are solved:

- the geopolitical and socio-economic roles and the results of the state's transition to the eighth technological order are described;

- a systematic analysis of technological ways is carried out;

- the image of the future eighth technological way is formed;

- the tasks of the state's entry policy into the eighth technological order are developed;

- the indicators of evaluating the effectiveness of the state's entry policy into the eighth technological order are described.

The object of the article is the eighth technological order/

The subject of the article is a model of the future of the eighth technological order.

To improve the efficiency of system development management processes, models are used [Pobol (2017), pp. 39-45; Komkov (2016), pp. 66-77]. Researchers note the great importance of industrial policy in the process of modernization of Russia [Bobrova and Bobrov (2015), pp. 307-317].

The development of clusters has led to the fact that experts recognize cluster policy as a new direction of economic policy [Vertakova (2015), pp. 11-14]. Regional innovation policy is practically used in France [Pavlova (2016), pp. 353-358]. An important part of the policy is the coordination of the interests of the parties [Feldman (2016), pp. 272-278]. Innovation policy is used to justify the strategy of corporations and firms [Glushchenko (2009), p.2]. Politics is increasingly being used as a management tool. Therefore, the specialists create a methodology of system and management approaches in political science [Glushchenko (2008) p.30-63]. Scientists describe the process of capitalist development as a sequence of six technological order [Aivazov (2012); Glazyev (2016), pp. 3-29]. Experts develop forecasts of the structure of a new technological order [Zagidullina et al. (2015), pp. 182-189]. Specialists are developing a methodology for strategic planning of the transition of organizations to a new technological order (way) [Orusova and Eliseeva (2015), pp. 82-89; Glushchenko (2021), p. 30-38]. However, this approach does not take into account the existence of a pre-capitalist period of technological development of the economy and society.

The methodological basis of such strategic planning is the theory of technological orders (structures) [Glushchenko (2021), p. 65-82; Glushchenko (2020), p. 12-20].

System analysis can be used to study technological orders [Gluchshenko (2021), pp. 22-34.]. The analysis shows that the technological order is a large multilevel system. The theory of multilevel (hierarchical) systems was proposed for the study and analysis of large systems [Mesarovich et al. (1973), p. 12-17]. Experts believe that the development of a new technological order affects the geopolitical power of the state. Zbigniew Brzezinski expressed this opinion: "America's economic dynamism is a necessary prerequisite for ensuring a dominant role in the world" [Brzezinski (2003), p.34]. The process of forming a new technological order 
can affect the geopolitical status and geopolitical status and risks of many states. For this reason, experts study the impact of geopolitical risk on the development and economic efficiency of innovative projects in the country [Glushchenko (1999), p. 46; Glushchenko (2006), p.200].

\section{METHOD}

The model of the eighth technological order is usually called a simplified representation of this order. This simplified representation is created specifically for solving the problems of design and analysis of the eighth technological order.

The paradigm of the entry of an organization (state, region, corporations, clusters, technological platforms, etc.) into the eighth technological order will be called the systematic unification of such elements of activity: the philosophy of activity; the ideology of activity; the policy of the organization. The concept of "paradigm" can be considered quite close to the concepts of "concept", "model", "method".

The concept can be interpreted as a systematic view of the process and results of the formation of this technological order in society and the economy. At the same time, the paradigm harmoniously includes such parts as: philosophy; ideology; organizational culture; politics; strategy and tactics of such a transition to a new technological order.

The philosophy of the organization's entry into the eighth technological order will be called the most general, wise view of this process and its results. There may be a philosophy of self-development of a new technological order. Such a philosophy implies the spontaneous self-development of a new technological order. This philosophy excludes the management of this process.

Another variant of this philosophy should be recognized as the philosophy of purposeful influence of the heads of organizations on the process of entering these organizations into the eighth technological order. The practical significance of the philosophy of the organization's entry into the new technological way is to substantiate the principles of the policy of managing the process of organizations ' entry into the eighth technological way.

The following provisions can be called the principles of the entry of organizations into the eighth technological order:

- the principle of focusing on achieving greater comfort and safety for the population;

- the principle of scientific justification in managing the process of entering an organization into a new technological order;

- the principle of rational use of the available resources of society and the economy;

- the principle of minimizing conflicts in the process of forming a new technological order;

- the principle of minimizing losses in the process of transition to a new technological order.;

- the principle of managing the efficiency and risks of this process and others.

These principles can become the values of the organizational culture of the management system of the organization's entry into a new technological order.

Let's agree to call the organizational culture of the organization's entry into a new technological way: norms of behavior; beliefs; values of the organization; ways of responding to the problems of the organization's personnel in this process. 
The ideology of the entry of organizations into the eighth technological order can be called: firstly, the way of distributing managerial power in this process; secondly, the key idea of forming a new technological order (improving the safety and comfort of people's lives).

The policy of entering organizations (state, region, corporations, clusters, technology platforms, etc.) into the eighth technological order in this article will be understood as a set of measures. Such a policy includes a set of measures aimed at: modernization of the production capacities of organizations; modernization of the products of these organizations; improvement of the organization's management systems; design of new types of technologies (nanotechnologies, neurotechnologies, digitalization technologies, information technologies, resource-saving technologies, environmentally friendly technologies); the introduction of these new technologies into the products of previous technological orders; the development of new economic and social production institutions; [Glushchenko (2021)], etc. The activities included in such a policy should be harmonious and coordinated with each other.

The policy of entering the economy and society into the eighth technological order includes strategy and tactics. The strategy is responsible for the long-term perspective of the entry of organizations into a new technological order [Glushchenko, V. V. (2021)]. Tactics ensures the current implementation of strategic plans, taking into account the need to fulfill such requirements: the sustainable development of this process of entering a new technological order; ensuring the solvency of the organization and others.

The subjects of the paradigm formation should understand that the "technological order (way)" is a complex multi-level (hierarchical) system. Therefore, the main research methods should be: the theory of hierarchical systems [Mesarovich et al. (1973), p.12-17]; system approach; system analysis; search heuristic forecasting and others. The subjects of the paradigm development should take into account that the authors of the theory of large systems consider: 1. "First of all, the very concept of system complexity depends on the point of view. What seems to a psychologist to be a complex or large system may turn out to be just an elementary link in the eyes of an economist"; 2. "We can even say that the importance and wide prevalence of multi-level systems are not yet well understood" [Mesarovich et al. (1973), p.12-17].

This opinion of the authors of the theory of large systems is confirmed by the practice of studying the problems of the formation of technological orders by economists. Representatives of economic science (economists) they consider the technological structure as a purely economic system [Glazyev (2016)]. With this approach, economists suggest that the technological structure means a system of key global institutions. At the same time, economists believe that the subject of the development of the technological structure is the process of expanded reproduction of capital [Glazyev (2016)]. With this approach, there is no place for the production technologies themselves in the technological order.

It is more logical to assume that the structure of the technological order (as a large system) includes: firstly, the technological basis of the organization; secondly, the system of industrial and social relations( institutions); thirdly, methods of personnel management and its organization; fourth, forms of doing business; fifth, the world order and more. At the same time, the technological basis of the organization is primary. For this reason, all economic and humanistic elements should correspond to the specifics of the technological basis of organizations. 
The paradigm (philosophy, ideology, policy) of the entry of organizations into a new technological order should be based on the methodology of the system approach. The systematic approach consists in studying and considering all the elements (parts) and/or properties of the technological order (object of research) in their mutual connection.

The system analysis of the eighth technological order can be called: determining the structure of this mode; establishing the nature of structural connections of elements; studying the properties of elements; studying the composition and properties of the entire technological order as a whole.

The system analysis carried out in this article shows the presence of a system connection between the technological basis of organizations and the factors of the world order [Glushchenko (2020)]. The analysis shows that there is a systemic influence of the technological basis of organizations on the following elements: types of the state; types of money (gold, credit money; mottos; cryptocurrencies [Glushchenko (2009)]); management methods in organizations; the type of the world currency system; forms of doing business in the economy, in the corresponding historical and, at the same time, technological periods of development.

On this basis, we will agree under the concept of "technological order" to understand the system integration into a single whole of such elements: the technological basis of production in the economy and society; social production relations; world order; types of business processes in the economy; management methods and tools; concepts of personnel management of organizations in the economy and society at a certain stage of the historical, technological, economic, social, cultural process of economic and social development.

The main provisions of the general theory of technological orders are described in [Glushchenko (2021); Glushchenko (2020), p. 12-20]. Further development of the general theory of technological orders should become an effective methodological tool for forming the paradigm of organizations ' entry into a new technological order.

An example of a system analysis of the course of technological development of the economy and society is given in Tables 1,2 . In Table 1 , a system analysis of the structure and content of elements of technological orders is carried out.

\begin{tabular}{|c|c|c|c|}
\hline $\begin{array}{c}\text { № } \\
\text { п/п }\end{array}$ & $\begin{array}{l}\text { Properties of technological } \\
\text { orders (structures) } \\
\text { /number orders, } \\
\text { rs, time period; names } \\
\text { technological orde }\end{array}$ & $\begin{array}{l}\text { Types of production } \\
\text { enterprises }\end{array}$ & New types of products \\
\hline (1) & (2) & (3) & (4) \\
\hline 1. & $\begin{array}{l}\text { "1st" technological order; } \\
\text { time period } 2000 \mathrm{BC}- \\
9 \text { th century AD; horse } \\
\text { traction; }\end{array}$ & Family, community & $\begin{array}{l}\text { Natural raw materials, } \\
\text { agricultural products, transport } \\
\text { services }\end{array}$ \\
\hline 2. & $\begin{array}{l}\text { "2nd" technological order; } \\
\text { Time period 9th century- } \\
\text { 1770; Windmill, a water } \\
\text { mill; }\end{array}$ & $\begin{array}{l}\text { Family, clan, craftsman, } \\
\text { miller }\end{array}$ & $\begin{array}{l}\text { Flour, sunflower oil; products of } \\
\text { mechanical processing of } \\
\text { agricultural products }\end{array}$ \\
\hline
\end{tabular}


Creating A Model of The Future of The Eighth Technological Order

\begin{tabular}{|c|c|c|}
\hline $\begin{array}{l}\text { 3. "3rd" technological order; } \\
\text { Time period 1770-1830; }\end{array}$ & $\begin{array}{l}\text { Textile manufactories, } \\
\text { Enterprises; }\end{array}$ & $\begin{array}{l}\text { Machine-made fabrics, } \\
\text { manufactory products }\end{array}$ \\
\hline
\end{tabular}

$\begin{array}{cll}\text { 4. "4th" technological order; } & \text { International } & \text { Steam engines; mechanisms; } \\ \text { Time period 1830-1880; } & \text { monopolies } & \text { locomotives, rails; sleepers; }\end{array}$
steam engine;
5. "5th" technological order; Multinational Cars, diesel locomotives, Time period 1880-1930; corporations,
airplanes, washing machines, refrigerators; radio, telegraph electric motor and internal combustion engine;

6. "6th" technological order; Multinational Time period 1930-1970; electronic computers;

\section{corporations,}

The " 7th" technological order;

Time period 1970-2010; microelectronics and microprocessors;

8. The " 8th " technological order;

Time period 2010-2040; nanotechnologies and neurotechnologies;
Multinational corporations, virtual corporations; strategic alliances of corporations

global information systems; clusters; technology platforms

Source: developed by the author

Table 1 System analysis of the structure and elements of technological orders (end)

\begin{tabular}{|c|c|c|c|}
\hline $\begin{array}{c}\text { № } \\
\text { п/п }\end{array}$ & $\begin{array}{c}\text { Properties of } \\
\text { technological orders } \\
\text { (structures) } \\
\text { /number, names } \\
\text { technological orders, } \\
\text { time period }\end{array}$ & $\begin{array}{l}\text { World order, socio- } \\
\text { economic formation; } \\
\text { the form of the state }\end{array}$ & $\begin{array}{l}\text { Type of money; } \\
\text { international monetary system }\end{array}$ \\
\hline (1) & (2) & $(5)$ & (6) \\
\hline 1 & $\begin{array}{c}\text { "1st" technological } \\
\text { order; } \\
\text { time period } 2000 \mathrm{BC} \\
- \\
\text { 9th century AD; } \\
\text { horse traction; }\end{array}$ & $\begin{array}{l}\text { Individual goods (grain, } \\
\text { cattle,furs) are } \\
\text { equivalent; money } \\
\text { changers and usurers }\end{array}$ & $\begin{array}{l}\text { communal and tribal system; slavery; } \\
\text { feudalism; communities; principalities; } \\
\text { kingdoms }\end{array}$ \\
\hline 2 & $\begin{array}{l}\text { "2nd" technological } \\
\text { order; } \\
\text { Time period 9th } \\
\text { century-1770; } \\
\text { Windmill, a water } \\
\text { mill; }\end{array}$ & $\begin{array}{l}\text { feudalism; } \\
\text { principalities; } \\
\text { kingdoms; land } \\
\text { empires }\end{array}$ & $\begin{array}{l}\text { Gold as a universal equivalent; money } \\
\text { changers and usurers; receipts and bills } \\
\text { of exchange; monasteries as } \\
\text { repositories of gold }\end{array}$ \\
\hline 3 & $\begin{array}{l}\text { "3rd" technological } \\
\text { order; } \\
\text { Time period } 1770- \\
\text { 1830; } \\
\text { Textile machines; }\end{array}$ & $\begin{array}{l}\text { monarchies; maritime } \\
\text { empires; capitalism; }\end{array}$ & $\begin{array}{l}\text { National gold currencies; paper money; } \\
\text { central and commercial banks; stock } \\
\text { exchanges; securities }\end{array}$ \\
\hline
\end{tabular}




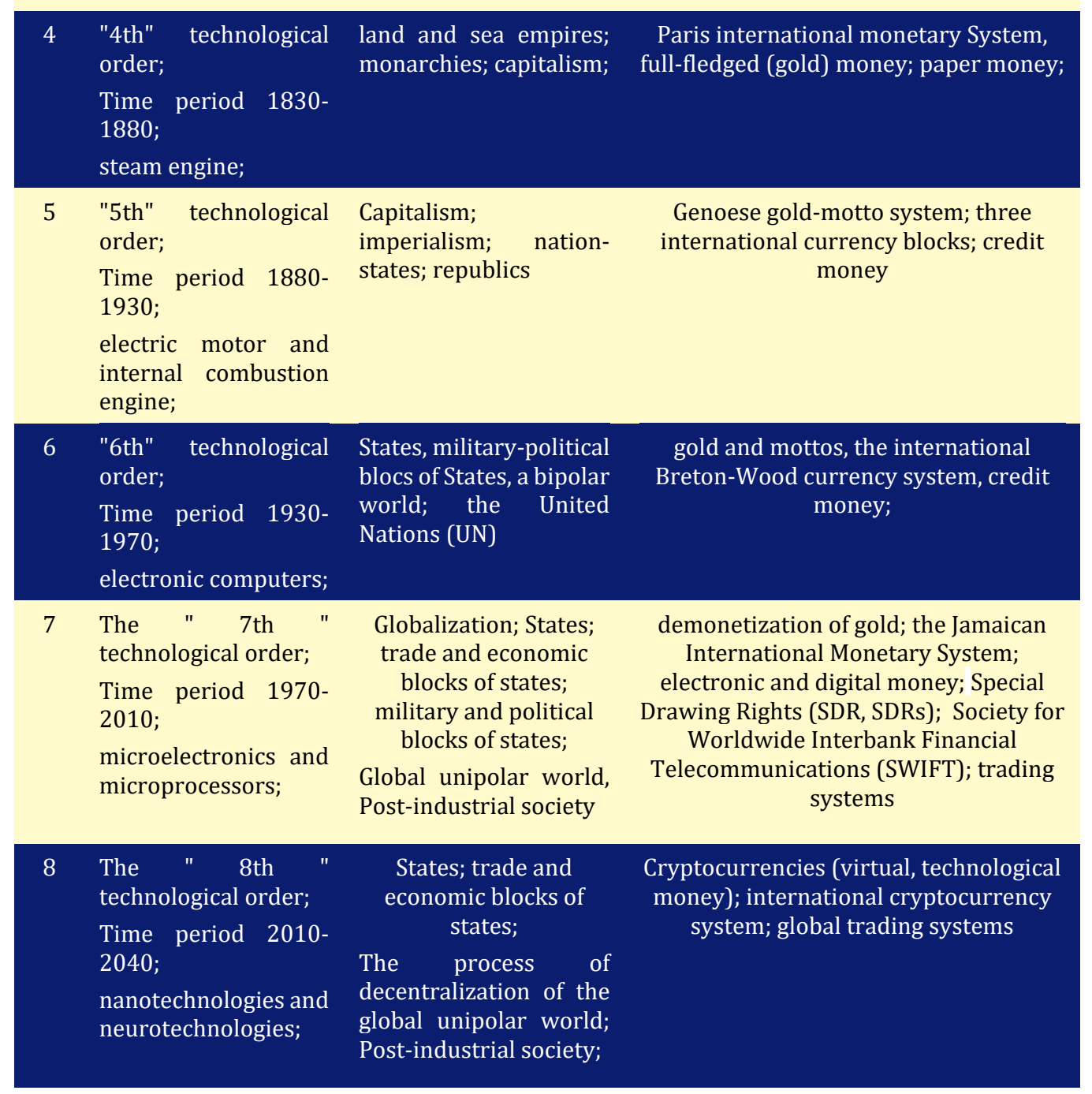

Source: developed by the author

The system analysis of the entire historical technological process of the development of modern civilization carried out above allows: to form descriptive models of all technological structures that took place; to form a descriptive model of the eighth technological structure. A descriptive model of the eighth technological mode will be obtained in this article by combining descriptions of elements of this mode. To do this, you need to combine the contents of rows \# 8 of the tables given in this article.

This descriptive model of the eighth technological order acts as an image of the future for the current period of historical and technological development.

The system analysis of the entire historical technological process of the development of modern civilization carried out above allows: to form descriptive models of all technological structures that took place; to form a descriptive model of the eighth technological structure. A descriptive model of the eighth technological order will be obtained in this article by combining descriptions of elements of this order. To do this, you need to combine the contents of rows \# 8 of the tables given in this article.

This descriptive model of the eighth technological order acts as an image of the future for the current period of historical and technological development. 

elements.

The image of the future eighth technological order may include such structural

1) New elements in the technological basis of organizations: nanotechnologies; neurotechnologies; information technologies; digitalization technologies; resource-saving technologies; environmentally friendly technologies [Glushchenko (2020), p. 12-20].

2) The sector of advanced economic development: the service sector, including science and education.

3) The main direction of the development of the monetary system: cryptocurrencies, settlements on the Internet.

4) Direction of development of management systems: distributed management systems; management of social development of personnel.

5) Methods of competition between organizations: at the level of organizational cultures, organizational design and company values.

6) Key types of resources: intellectual and financial resources and others.

The second way to represent the image model of the eighth technological order is the formation of a table. This table will include the name and description of the content of the factors of the model of the eighth technological order. Such a factor model of the eighth technological order is shown in Table No. 3.

\begin{tabular}{|c|c|c|}
\hline $\begin{array}{l}\text { № } \\
\text { п/п }\end{array}$ & $\begin{array}{c}\text { Factors of the eighth technological } \\
\text { order }\end{array}$ & Description of the factors of the eighth technological order \\
\hline
\end{tabular}

(1)

1.

Time period

2. Types of production enterprises

3. Technologies, methods and scales of production; structure and characteristics of labor

4. World order, socio-economic
formation $\quad \begin{gathered}\text { States; trade and economic blocks of states; } \\ \text { The process of decentralization of the global unipolar world; Post- } \\ \text { industrial society; }\end{gathered}$

5. Type of money; international monetary system

6. Forms of development of science and innovation

Cryptocurrencies (virtual, technological money); international cryptocurrency system; global trading systems

global information systems; clusters; technology platforms

Nanotechnologies, neurotechnologies, information technologies; development of mentality and social development of employees

Clusters, technology platforms, university research laboratories, laboratories of coprorations

$\begin{array}{cc}\text { 7. } & \begin{array}{c}\text { Economic policy, Types of } \\ \text { organizational structures in the } \\ \text { economy }\end{array}\end{array} \begin{gathered}\text { Approved innovation policy; clusters, technology platforms; } \\ \text { Organizational architecture; organizational design and culture }\end{gathered}$
economy 
11. New types of production

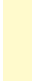

Production of materials with specified properties, nanotechnology production, environmentally friendly production;

3-D printing products, information products, transformation of human thinking (clip thinking)

12. The main trend in the development of human rights

Ensuring compliance with the rights of minorities

Source: developed by the author

In turn, this image of the future becomes the basis for the formation of the paradigm of the development of the eighth technological order. At the same time, the very paradigm of such development acts as a philosophical and ideological basis for developing a policy for the transition of organizations to the eighth technological order.

The role of the paradigm of development of the eighth technological order is related to the following. The formation of the correct paradigm of the development of the eighth technological order will allow the organization to get the maximum effect in the process of technological development.

Let us explain the significance of the effective development of the eighth technological order on the example of such an organization as the state. The formation of the eighth technological order means the transition of the technological basis of advanced organizations to this eighth technological level. The products of enterprises of the eighth technological order will have a higher (eighth) technological level. For this reason, these products will be characterized by a higher monetary innovation multiplier. The innovative money multiplier shows how many times the cost of the final product exceeds the cost of raw materials and raw materials [Glushchenko and Glushchenko (2016)]. It is known that a modern automobile engine is about 30 times more expensive than the aluminum from which it is made. Timely modernization of this engine through the use of technologies of the eighth technological order will increase its quality. The possibility of such modernization is confirmed in [Glushchenko and Glushchenko (2016)]. At the same time, the innovative money multiplier will increase. For example, this multiplier will become equal to 37. This means that a particular company will receive more profit. This means an increase in revenues to the country's budget. This means an increase in the hardness of the national currency. This means increasing the stability of the national monetary system. At the same time, the increase in the stability of the national monetary system will be the result of the fact that the innovative money multiplier will be significantly larger than the bank money multiplier. As is known, the bank multiplier characterizes the effect of increasing (multiplying) money on deposit accounts of commercial banks as a result of their movement from one economic entity to another. In this case, the total value of goods is greater than the money supply in the economy. Therefore, in this case: there is no development of inflation; the national currency is solid.

At the same time, the gross domestic product increases; the volume of budget funds increases; the country's development opportunities grow.

If the modernization of the economy is not carried out, then there is a drop in the competitiveness of products. In this case: the gross domestic product is falling; the amount of budget funds is decreasing; the socio-economic crisis is developing; the geopolitical situation of the state is deteriorating.

The paradigm of an organization's entry into the eighth technological order can be formed on the basis of consensus or on a confrontational basis. The paradigm of the development of the eighth technological order in the organization is consensual, 
if all subjects agree with its provisions. This paradigm has a confrontational character if its implementation is accompanied by a conflict.

The importance of forming an effective paradigm for the development of the eighth technological order is confirmed by such a historical example.

Example №1. In 1940 (the sixth technological order), a mental conflict arose between the employees of the USSR Academy of Sciences. This conflict is described in [Kolchinsky et al. (2018)]. As a result of this conflict, genetics and cybernetics were declared false sciences (pseudosciences). Cybernetics and genetics were practically banned. Academician N. I. Vavilov and other supporters of these scientific directions were repressed. N. I. Vavilov was later posthumously rehabilitated. The technological result of this conflict was the lag of the USSR in the field of computer technologies. This has reduced the competitiveness of the economy's products. This technological lag, presumably, had disastrous consequences for the country.

This example shows how the system of social production relations (institutions) can slow down the development of technologies. This gives reason to assert that there is an interconnectedness of the specifics of technologies and the characteristics of public institutions. When institutions and technologies do not match, a crisis arises. The crisis will continue until the nature of the institutions comes into line with the requirements of the technologic.

Therefore, the formation of an effective paradigm and policy for the transition of organizations to the eighth technological order is very important for organizations in the 21st century.

Therefore, the paradigm of transition to a new technological order should include measures aimed at detecting mental conflicts. Great attention should be paid to the rule of law and respect for human rights [Glushchenko (2018)].

If we talk about the composition of technological directions in which, as predicted, the development of the eighth technological order will take place, then we can say the following.

The method of system analysis of the technological structure is described in [Gluchshenko (2021), pp. 22-34]. The paradigm and policy of transition to a new technological order should include measures: firstly, for the development of new technologies; secondly, measures for the development of social institutions [Glushchenko (2021)].

It should be remembered that it is the disharmony between the essence of technologies and the content of production institutions that is the source of the crisis [Glushchenko (2008)].

Some researchers believe that the eighth technological order will be based on nanotechnologies [Glazyev and Kharitonov (2009)]. However, a more advanced system analysis has shown that the technological basis of this technological order will be: neurotechnologies; nanotechnologies; information technologies; resourcesaving technologies; digitalization technologies; environmentally friendly technologies [Glushchenko (2020), p. 12-20]. The sources of new scientific achievements will be: a deeper penetration into the structure of the material world (nanotechnology); a more adequate knowledge of the work of the human brain (neutrotechnology); more rational use of raw materials; minimizing damage to nature and more.

At the same time, as already noted, the subject of the new technological way will be to increase the level of comfort and safety of people's lives. The solution of these tasks will also be connected with the problem of resolving contradictions between: technologically developed states and lagging states; between technologically leading social groups and a technologically lagging part of the 
population, and others. For a more complete reflection of the specifics of the development of individual social groups of the population, a systematic analysis of the properties of the technological structure may be required. In Table 2, a systematic analysis of the properties of technological structures that took place in the history of mankind is carried out.

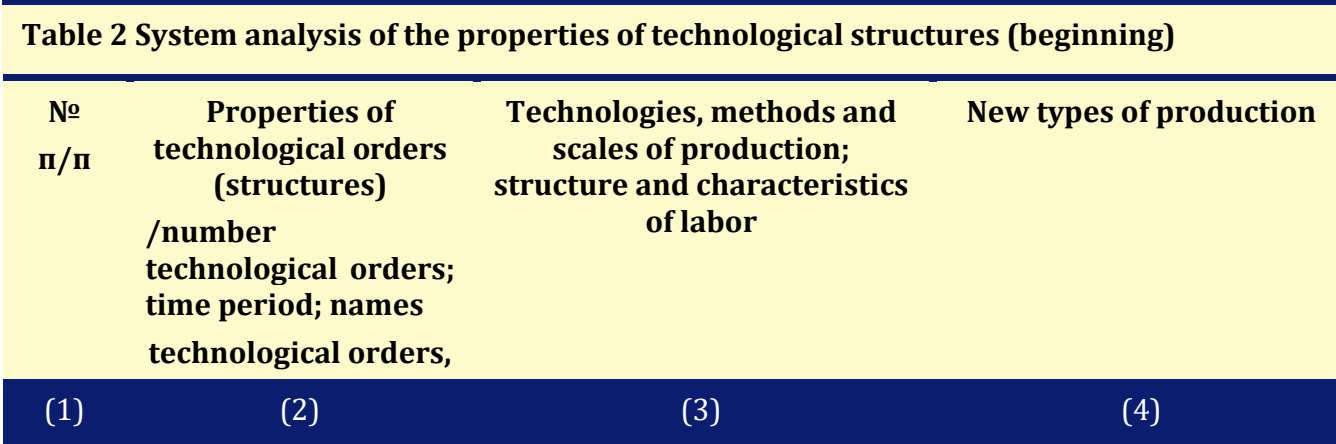

\begin{tabular}{|c|c|c|c|}
\hline 1. & $\begin{array}{l}\text { "1st" technological } \\
\text { order; } \\
\text { time period } 2000 \mathrm{BC}- \\
\text { 9th century } \mathrm{AD} ; \\
\text { horse traction; }\end{array}$ & $\begin{array}{l}\text { Technologies of manual, single } \\
\text { and small-scale production; } \\
\text { simple abstract work }\end{array}$ & $\begin{array}{l}\text { Mechanized processing of } \\
\text { materials based on horse- } \\
\text { drawn traction; transport } \\
\text { services based on horse- } \\
\text { drawn traction }\end{array}$ \\
\hline 2. & $\begin{array}{l}\text { "2nd" technological } \\
\text { order; } \\
\text { Time period 9th } \\
\text { century-1770; } \\
\text { Windmill, a water mill; }\end{array}$ & $\begin{array}{l}\text { Technologies of manual, single } \\
\text { and small-scale production; } \\
\text { simple abstract work }\end{array}$ & $\begin{array}{l}\text { mechanized production of } \\
\text { flour, oils based on the use of } \\
\text { vert energy and water }\end{array}$ \\
\hline 3. & $\begin{array}{l}\text { "3rd" technological } \\
\text { order; } \\
\text { Time period 1770- } \\
\text { 1830; } \\
\text { Textile machines; }\end{array}$ & $\begin{array}{l}\text { Mechanized technologies of } \\
\text { mass production; professional } \\
\text { labor skills }\end{array}$ & $\begin{array}{l}\text { Mechanized textile } \\
\text { production of fabrics }\end{array}$ \\
\hline 4. & $\begin{array}{l}\text { "4th" technological } \\
\text { order; } \\
\text { Time period 1830- } \\
\text { 1880; } \\
\text { steam engine; }\end{array}$ & $\begin{array}{c}\text { Mechanized mechanical } \\
\text { processing and transport } \\
\text { services based on a steam } \\
\text { engine }\end{array}$ & $\begin{array}{l}\text { Mechanized technologies of } \\
\text { mass production of } \\
\text { machine-building products, } \\
\text { knowledge and professional } \\
\text { training of employeesp }\end{array}$ \\
\hline 5. & $\begin{array}{l}\text { "5th" technological } \\
\text { order; } \\
\text { Time period 1880- } \\
1930 ; \\
\text { electric motor and } \\
\text { internal combustion } \\
\text { engine; }\end{array}$ & $\begin{array}{l}\text { Technologies of large-scale } \\
\text { conveyor production; special } \\
\text { management and labor } \\
\text { competencies }\end{array}$ & $\begin{array}{l}\text { Mechanized mechanical } \\
\text { processing; transport } \\
\text { services based on an electric } \\
\text { motor and an internal } \\
\text { combustion engine }\end{array}$ \\
\hline 6. & $\begin{array}{l}\text { "6th" technological } \\
\text { order; } \\
\text { Time period 1930- } \\
\text { 1970; } \\
\text { electronic computers; }\end{array}$ & $\begin{array}{l}\text { Technologies of automated } \\
\text { large-scale production; } \\
\text { qualification requirements and } \\
\text { job descriptions for employees }\end{array}$ & $\begin{array}{l}\text { Production of electronic } \\
\text { computers and automated } \\
\text { production complexes }\end{array}$ \\
\hline 7. & $\begin{array}{l}\text { The " 7th " } \\
\text { technological order; } \\
\text { Time period 1970- } \\
\text { 2010; }\end{array}$ & \begin{tabular}{lrr}
\multicolumn{3}{l}{ Flexible automated production; } \\
competence cards and \\
qualification & cards & for \\
employees & &
\end{tabular} & $\begin{array}{l}\text { Automated production of } \\
\text { trace elements and printed } \\
\text { circuit boards, } \\
\text { microprocessor devices }\end{array}$ \\
\hline
\end{tabular}


microelectronics and microprocessors;

8. The " 8th technological order; Time period 20102040;

nanotechnologies and neurotechnologies;
Nanotechnologies, neurotechnologies, information technologies; development of mentality and social development employees
Production of materials with specified properties, nanotechnology production, environmentally friendly production

Source: developed by the author

Table 2 System analysis of the properties of technological structures (end)

$\begin{array}{cccc}\text { № } & \begin{array}{c}\text { Properties of } \\ \text { technological orders } \\ \text { (structures) }\end{array} & \begin{array}{c}\text { The paradigm of organization } \\ \text { management; the paradigm of } \\ \text { working with personnel }\end{array} & \begin{array}{c}\text { Economic policy, Types of } \\ \text { organizational structures } \\ \text { in the economy }\end{array} \\ \begin{array}{c}\text { technological orders, } \\ \text { time period; names } \\ \text { technological orders, }\end{array} & & \\ & \end{array}$

\section{(1)} (2)

(5)

(6)

1. "1st" technological order;

time period $2000 \mathrm{BC}-$

9th century AD;

horse traction;
Centralization, organization, control, labor stimulation, management as an art, unity of command, human relations
Informal economic policy traditional organizational structures

\begin{tabular}{|c|c|c|c|}
\hline 2. & $\begin{array}{l}\text { "2nd" technological } \\
\text { order; } \\
\text { Time period 9th } \\
\text { century-1770; }\end{array}$ & $\begin{array}{c}\text { The formation of requirements } \\
\text { for the manager, the theory of } \\
\text { power, the study of the impact of } \\
\text { automation }\end{array}$ & $\begin{array}{l}\text { Informal economic policy, } \\
\text { traditional organizational } \\
\text { structures }\end{array}$ \\
\hline & Windmill, a water mill; & & \\
\hline 3. & $\begin{array}{l}\text { "3rd" technological } \\
\text { order; } \\
\text { Time period 1770- } \\
\text { 1830; } \\
\text { Textile machines; }\end{array}$ & $\begin{array}{l}\text { Economic theory, financial } \\
\text { theory, the principle of } \\
\text { specialization of industrial } \\
\text { workers }\end{array}$ & $\begin{array}{l}\text { Informal economic policy, } \\
\text { traditional organizational } \\
\text { structures }\end{array}$ \\
\hline 4. & $\begin{array}{l}\text { "4th" technological } \\
\text { order; } \\
\text { steam engine; } \\
\text { Time period } 1830- \\
1880,\end{array}$ & $\begin{array}{l}\text { Theory of public services, } \\
\text { analysis of employee motivation }\end{array}$ & $\begin{array}{l}\text { Informal economic policy, } \\
\text { traditional organizational } \\
\text { structures }\end{array}$ \\
\hline 5. & $\begin{array}{l}\text { "5th" technological } \\
\text { order; } \\
\text { Time period 1880- } \\
\text { 1930; } \\
\text { electric motor and } \\
\text { internal combustion } \\
\text { engine; }\end{array}$ & $\begin{array}{l}\text { Scientific management, methods } \\
\text { of statistics in management, } \\
\text { personnel work }\end{array}$ & $\begin{array}{l}\text { Approved economic and } \\
\text { industrial policy, Functional } \\
\text { organizational structures }\end{array}$ \\
\hline 6. & $\begin{array}{l}\text { "6th" technological } \\
\text { order; } \\
\text { Time period 1930- } \\
\text { 1970; } \\
\text { electronic computers; }\end{array}$ & $\begin{array}{l}\text { Operational research, system } \\
\text { analysis, marketing, program- } \\
\text { target approach, personnel } \\
\text { management, personnel } \\
\text { motivation systems }\end{array}$ & $\begin{array}{l}\text { Approved economic and } \\
\text { industrial policy; strategic } \\
\text { management; product- } \\
\text { oriented organizational } \\
\text { structures of the company }\end{array}$ \\
\hline
\end{tabular}



technological order; Time period 19702010; microelectronics and microprocessors;

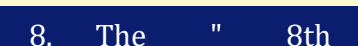
technological order; Time period 2010 2040; period 2010nanotechnologies and neurotechnologies;

Source: developed by the author

The following areas of work can be included in the structure of the paradigm of the organization's transition to a new technological order:

- development of proposals for the further development of methodological provisions of the general theory of technological orders;

- development of research on practical problems of the general theory of technological orders in specific sectors of the national economy and society;

- formation of a set of measures to improve the effectiveness of social development programs of society and individual social groups;

- development of legal norms and a set of measures aimed at the formation of technological platforms and clusters that carry out the development of new technologies of the eighth technological order (nanotechnologies; neurotechnologies; information technologies; digitalization technologies; resource-saving technologies; environmentally friendly technologies);

- formation of a system of measures aimed at the development of social and industrial institutions of the eighth technological order;

- creation of a multi-contour management system for the development of industries of a new technological order;

- development of a set of measures for the formation of a set of indicators to assess the effectiveness of the development processes of the eighth technological order, and much more. At the same time, all these directions of this paradigm should be coordinated with each other.

Let's consider these areas of the paradigm of the organization's transition to a new technological order in more detail. Proposals for the further development of the theoretical provisions of the general theory of technological orders may include the development of methodology as part of all the functions of this theory. These are the following functions of the scientific theory of technological structures: integrative function; methodological function; prognostic function; preventive function; function of knowledge socialization; instrumental function. The content of the function of the general theory of technological structures is reflected in more detail in the work [Glushchenko (2021)].

The category of events for the development of applied problems of the theory of technological orders by branches of the national economy can include the formation of branch directions of the theory of technological orders.

The practical geopolitical direction of the general theory of technological structures can solve the following tasks: forecasting geopolitical changes; assessing 
the geopolitical consequences of the development of a new technological order; developing adequate geopolitical measures, and others. The significance of this direction of the theory of technological orders is evidenced by the fact that the First and Second World Wars arose during the 5th and 6th technological orders. These wars were the result of changes in the economic power of States. In the middle of the 7th technological order, the collapse of the USSR occurred. This collapse was largely due to the technological lag of the USSR from the leading countries. As a result of the collapse of the USSR, the bipolar world was transformed into a unipolar world. It can be predicted that in the eighth technological order, the technological and economic differentiation of countries will increase. Therefore, the geopolitical results of the development of the eighth technological order will be even more ambitious.

The political science branch of the theory of technological orders can solve the following tasks: justification of rational changes in the system of state law; formation of an adequate scientific and technical policy; justification of changes in social and industrial policy during the eighth technological order.

The applied sociological direction of the general theory of technological orders can deal with the issues of forecasting: trends in demographic development; forecasting the social structure of society; estimating human life expectancy; forecasting changes in the sphere of family relations, and others.

The culturological branch component of the general theory of technological order can carry out studies of cause-and-effect relationships between the features of the technological order and cultural trends. This kind of interrelationships can be studied in the following areas: fiction; painting; theater and cinema; pop music and others.

The medical branch theory of technological orders will be of a practical nature. The medical branch theory of technological orders should investigate such problems: technical progress in the field of medical equipment; cause-and-effect relationships between the frequency of occurrence of various diseases and the characteristics of the technological order. For example, it should be recommended to study the dependence of the number of diseases of the heart and other organs on the characteristics of the technological order. Such studies allow you to carry out:

- prognosis of the development of various types of diseases during the eighth technological order;

- design new medical equipment based on new technologies;

- modernization of existing medical equipment by introducing technologies of the eighth technological order.

In the process of industry research, a systematic analysis of the development of certain industries can be carried out. For example, in the field of medicine, two tables can be developed. In one table, it can be recommended to display the change in the structure of the frequency of various diseases of the population, depending on the technological order. The second table can describe the process of development of medical equipment in the time periods of specific technological orders.

Within the framework of the paradigm of the state's entry into the eighth technological order, there should be a program for the development of individual technological platforms. These technology platforms should be engaged in the development and implementation of new technologies in practice. As already noted, new technologies include: nanotechnologies; neurotechnologies; information technologies; digitalization technologies; environmentally friendly technologies; resource-saving technologies. The tools for the development of such platforms are described in [Glushchenko (2020), pp. 44-63]. 
Within the framework of the paradigm of the state's entry into the eighth technological order, there should be a program for the development of new technological platforms. These technology platforms should be engaged in the development and implementation of new technologies in practice. As already noted, new technologies include: nanotechnologies; neurotechnologies; information technologies; digitalization technologies; environmentally friendly technologies; resource-saving technologies. The tools for the development of such platforms are described in [Glushchenko (2020), pp. 44-63].

However, new technologies will develop successfully only if new production institutions contribute to their development.

The mechanism of development of new industrial and social institutions of the eighth technological order is described in [Glushchenko (2021), pp. 554-563]. The process of forming a management system for the formation of the eighth technological order is presented in [Glushchenko (2020), p. 54-63].

Measures for the formation of a set of indicators for analyzing the effectiveness of the development processes of the eighth technological order will be described in the part called "Discussion" of this article.

It is recommended to include the commercialization of new technologies and innovations among the most important tasks. The process of obtaining economic benefits from the repeated use of new technologies should be organized in the national economy. Multiple introduction of new technologies can be called "technology multiplication". Such "technology multiplication" should be carried out by purposefully introducing these new technologies into existing products. The method of modernization of products or production capacities of firms when they enter the eighth technological order is as follows.

1) It is recommended to study the composition of each of the types of technologies of the eighth technological order (nanotechnologies, neurotechnologies, and others).

2) It is necessary to study the principle of operation of the structural elements of the modernization object.

3) Next, it is necessary to synthesize specific proposals to improve the comfort and safety of the practical use of the modernization object.

4) After that, it is necessary to analyze the possibility of introducing new technologies into an existing modernization object (products and production facilities of the company).

5) It is necessary to create a project for the introduction of a new technology into the object of modernization.

6) It is necessary to analyze and evaluate the real impact of the new technology on the comfort and safety of the modernization object.

7) It is recommended to obtain an assessment of the economic effect of the work on the modernization of this object.

The economic efficiency of the introduction of new technologies in the economy is determined by the number of such implementations. When a new technology is introduced, it is systematically combined with the technologies of previous technological orders. To characterize the intensity of the process of introducing new technologies in the economy, we will introduce the concept of "technology multiplication". The concept of "multiplication of technologies" in this paper will act as an integral characteristic of the number and depth of integration of new and old technologies in the economy during the transition to a new technological order. The concept of "multiplication of technologies" allows us to assess the economic 
efficiency of using new technologies in the national economy of the country. The greater the number of integrations of new technologies with technologies of previous technological orders, the higher the economic efficiency of new technologies.

\section{DISCUSSION}

The subjects of the development of the paradigm for the entry of organizations into the eighth technological order can be: international organizations; national academies of sciences; national governments; political parties; top managers of corporations; heads of clusters and technology platforms; developers of new technologies themselves, and others.

As subjects of the development of the paradigm of the organization's entry into the eighth technological order, they can develop their ideas. For example, political parties can present their ideas on such issues: strengthening the geopolitical position of the state; optimal distribution of productive forces in the economy; increasing the efficiency of the process of socio-economic development; harmonization of social and industrial relations; development of culture; improvement of medical services for citizens and other issues. In the Parliament, political parties can take legislative initiatives. These draft laws can be focused on the synthesis of legal norms that contribute to the acceleration of the development of the eighth technological order.

At the same time, political parties should provide support and mentoring to those entities whose activities contribute to the formation of the eighth technological order in the economy and society. Such social and economic assistance (mentoring) in relation to the developers of new scientific and technical ideas is very important. Such assistance to developers is especially important in the initial period of development of the eighth technological order.

Public business associations should also provide support to developers of new technologies.

An important element of the support system for new technologies is the work of business angels and venture funds. Developed countries have their own systems of support and mentoring of innovations. In countries where such a mentoring system does not exist, there is a "brain drain". This reduces the pace of development of such states.

Therefore, the paradigm of organizations entering the eighth technological order should contain measures to support developers of new technologies.

A necessary element of effective management of the entry of organizations into the eighth technological order is the formation of a system of indicators of the effectiveness of this process. It is proposed to include the following characteristics in such a system of indicators:

- the share of products (goods and services) belonging to the eighth technological order in the total output of the national economy;

- the share of production technologies related to the eighth technological order in the technological basis of the national economy;

- the share of employees engaged in the production processes of the eighth technological structure;

- the amount of revenue per employee at enterprises of the eighth technological structure;

- the cost of fixed assets of enterprises belonging to the eighth technological order; 
- the contribution of enterprises of the eighth technological order to the gross domestic product of the country;

- the rate of annual increase in the share of firms of the eighth technological order in the gross domestic product of the state;

- the share of fixed assets of the national economy that are used in the activities of organizations belonging to the eighth technological order;

- the volume of "brain drain" or the influx of high-tech personnel into the economy.

In order to determine these indicators, it is necessary to propose criteria on the basis of which an organization or a product can be attributed to the eighth technological order.

In this article, it is proposed to create a rating of states that best solve the problem of entering the eighth technological order. In this case, the indicators described above can be used.

In the process of developing a paradigm for the entry of organizations into the eighth technological order, it is necessary to take into account the situation of a qualitative leap in the development of scientific and technological progress. Such a leap is associated with the formation of the eighth technological order. At the same time, the fact of the existence of a qualitative leap in scientific and technological progress makes it impossible to use such research methods: the continuation of existing trends; the use of statistical methods; the use of analytical models. In the conditions of a qualitative leap in the development of the forecasting object, heuristic methods gain an advantage.

Another characteristic feature of the process of synthesis of the paradigm of the organization's entry into a new technological order can be considered the following. Such a paradigm should be systemic in nature. This means that in such a paradigm, elements that have a technical, economic, and organizational nature should be systematically combined.

At the same time, the very process of forming such a paradigm can be recognized as a research strategic project. This project of developing such a concept is based on the application of methods of a number of sciences: geopolitics, economics, sociology, technical sciences, theory of technological order and others.

Therefore, the third feature of the process of synthesis of the paradigm of the organization's entry into the eighth technological order is as follows. All proposals included in the paradigm of entering the eighth technological order must be scientifically justified. The lack of scientific justification for the activities included in this paradigm can lead to errors. Let's pay attention to a possible example of such an alleged error in the process of global anti-crisis management.

Example № 2. As you know, on November 7, 2010, a well-known article was published in the Financial Times newspaper. This article was widely covered in the business press [Parmy (2010)]. In this article, a proposal was made to partially return to the "gold standard". This proposal contradicted the decisions of the Jamaican International Monetary Conference on the demonetization of gold. However, this proposal was supported by global and national banking and financial circles. Central and commercial banks began to implement this recommendation of the global monetary authorities. Therefore, an intensive purchase of gold by central and commercial banks began. The growing demand for gold has led to an increase in its value. Therefore, by July 2011, the price of a troy ounce of gold (weighing 31.4 grams) on the global market was already about $\$ 1920$ per ounce. In this situation, analysts made forecasts that by the end of 2011 , the price of gold will exceed $\$ 2000$ 
per troy ounce. This development of events was considered as a negative trend in the financial market. Moreover, the crisis in the gold market through the inclusion of the" domino effect " could lead to global economic, social and political destabilization.

Therefore, in July 2011, the current situation on the gold market was subjected to a systematic analysis in the book [Glushchenko (2012), p. 62-63].

As a result of such a systematic analysis, an expert evaluation opinion was expressed that the reason for such a negative situation could be a proposal for a partial return to the gold standard.

As a result of the system analysis, it was proved that this proposal does not take into account system connections in the economy. Therefore, such a proposal can: probably lead to an increased demand for gold; it is possible to stimulate the outflow of money from the real sector of the economy to the financial sector, and others. An analysis of the legal basis of such a proposal showed that it may not meet the decisions of the Jamaica Conference.

When analyzing the methodological basis of such a proposal, it was noted that, presumably, the proposal to partially return to the gold standard may not meet a well-known theoretical requirement. This requirement is that there should be a single methodology for building a monetary system. Therefore, the proposal for a partial return to the gold standard violates the requirement of unity of the methodology for building the monetary system.

In the future, a more detailed analysis of the proposal for a partial return to the gold standard was also carried out in the book [Glushchenko (2012), p. 14]. This second book was published by the author at the end of 2011.

The authorities of the United States and Russia, the banking community of Russia were informed about the results of these studies [Glushchenko (2012), p. 6263; Glushchenko (2012), p. 14].

Presumably, the analysis of statistics shows that since the publication of the book [33, p. 62-63 ] in mid-July 2011, the price of gold began to decline on the world market. This trend did not correspond to the forecasts of bank analysts, which were published before the publication of the book [Glushchenko (2012), pp. 62-63].

By the beginning of 2012, the price of a troy ounce of gold was already about $\$ 1,600$ per ounce. In 2014 , the cost of one ounce of gold was about $\$ 1400$ [Glushchenko (2014), p. 250-255]. Subsequently, the price of gold decreased to about $\$ 1,260$ per troy ounce in 2017 . The growth of gold prices resumed only in 2020.

Presumably, the results of scientific research [Glushchenko (2012), p. 62-63; Glushchenko (2012), p. 14; Glushchenko (2014), p. 250-255] could affect the monetary policy and banking practice of buying gold. Probably, as a result of such changes, the price of one ounce of gold may decrease by about \$500-650 per ounce.

Such a horizontal (historical) analysis of gold price statistics shows that presumably the reason for the surge in gold prices in 2011 could be the proposal to partially return to the gold standard?

An expert assessment of the estimated economic effect of such a systematic analysis of the proposal to partially return to the gold standard may look like this.

Let's assume that the amount of bank (thesaurus) gold alone in the world is about 60,000 tons.

Let's perform the following actions.

1) Divide 60,000 tons of gold by the weight of one troy ounce (31.4 grams) of gold. 
2) The resulting number of troy ounces $(910,828,025)$ is multiplied by the value of the price reduction per ounce $(\$ 650)$.

3) This calculation suggests that the probable economic effect of the described system analysis [Glushchenko (2012), pp. 62-63; Glushchenko (2012), p. 14; Glushchenko (2014), pp. 250-255 ] could be around \$ 1000000000000 (one trillion dollars)?

In 2014, that amount was two and a half times more than the initial cost of the stabilization Fund of the European Union; approximately three times the budget of Russia?

This example may allow us to draw the following conclusions: the high price of possible mistakes; the need for preliminary discussion of the proposed solutions by the scientific community; the need to form a unified methodological approach in the process of developing the monetary subsystem of a new technological structure?

It should be noted that additional opportunities for analyzing the proposal for a partial return to the gold standard are provided by a system analysis within the framework of the theory of technological orders. Table 1 of this article describes the historical dynamics of changes in the international monetary system over the entire period of technological development. We will conduct a systematic analysis of the development of the international monetary system. This system analysis shows the following.

1) Throughout the entire historical period of development, Gresham's Law applies: "The worst money displaces the best from circulation." Does the proposal to partially return to the gold standard contradict Gresham's law?

2) To justify anti-crisis measures in the field of the monetary system, a scientific theory of post-industrial money is necessary.

3) The technological theory of money can be considered as a scientific theory of the post-industrial monetary system [Glushchenko (2009), p. 7-16; Glushchenko (2012), p. 2; Glushchenko (2012) ,p. 14].This thesis is also confirmed by the fact that the intensive development of cryptocurrency money systems begins after 2009 .

The third methodological feature of the concept of transition to a new technological order should be recognized. The point is that such a paradigm should be formed throughout the entire life cycle of a new technological order in the global and national economy. Therefore, such a paradigm of transition to the eighth technological order should be developed for the period up to 2030-2040. The fourth feature of such a paradigm may be that this paradigm should include risk analysis. Based on the results of such an analysis, a list of measures aimed at reducing the risks of the economy entering the eighth technological order should be compiled. The fifth characteristic feature of such a paradigm is that the methodology of predictive analysis should be used. Such a predictive analysis is aimed at analyzing the future situation. This predictive situation is formed in the process of entering the 8th technological order.

The sixth feature of the considered paradigm is that the content of this paradigm should be periodically revised in accordance with the changes observed in the external and internal environment of society and the national economy.

The following (seventh) feature of this paradigm should be recognized: it should initially be formed as a flexible document. Such a paradigm should initially include the possibility of making changes to goals and tools in the event that a change in the situation occurs. 
In addition, it should be borne in mind that the process of practical implementation of the approved paradigm is actually a process of economic restructuring. This will also cause changes in the life of society.

In the process of restructuring society and the economy, there may be a need for rebranding public authorities (corporations, clusters, technology platforms) and other entities entering a new technological order.

In the process of restructuring society and the economy, it may be necessary to rebrand state bodies (corporations, clusters, technology platforms) and other entities entering a new technological order.

Such a rebranding can be used by an organization (state, corporation, and others) to strengthen its position in the international arena and markets. At the same time, rebranding allows for internal coordination of activities in the organization.

The definition of the concept of "brand" is given in [Knyshova (2009), p. 206]. We will call the brand a "corporate" sign that reflects the style and effectiveness of the management system in the organization. This brand reflects the competitive position of the organization in the international and national system of geopolitical management.

The positioning and use of such a brand can affect the effectiveness of geopolitical and corporate governance.

The continuation of the global crisis [Glushchenko (2018),pp. 333-354] requires changes in the work of organizations ' management systems. Such changes should improve the perception of management processes in the international community, in the markets, in the work of personnel.

One of the most effective tools can be rebranding. At the same time, it is possible to apply the methods used by transnational corporations to the system of public administration. This is due to the fact that the state (to a certain extent) can be considered as a geopolitical non-profit corporation in the post-industrial global world [Glushchenko (2007)].

Under the rebranding of the management system in this article, it is proposed to mean a purposeful change in the image and brand. Rebranding is carried out in order to improve the perception of the management system in the external and internal environment of the organization.

The decision on rebranding should be scientifically justified. To this end, it is necessary to form the methodological foundations of such a rebranding.

The philosophy of rebranding an organization is understood as the most general wise idea of the need, conditions, concept, process and expected results of such a rebranding.

Therefore, there should be an element in the paradigm that describes the rebranding options. Such rebranding should be accompanied by the development of a private rebranding program for a specific subject of the eighth technological order.

Presumably, when forming a general concept of transition to a new technological order, it may happen that an essential element of such a concept may be a proposal, an event that was not initially accepted. However, a deeper analysis of such a rebranding proposal, the implementation of a creative modernization of this proposal, presumably, can allow such an improved project to be implemented.

Example No3. The idea of the need to form a philosophy of rebranding the public administration system was formulated during the preparation of a report at an international scientific conference at the Faculty of Public Administration of 
Moscow State University. The theses of the report on this under the title "The philosophy of rebranding of domestic public administration" were posted on the Lomonosov portal on 23.03.2019. However, the organizing committee of this conference did not approve these theses. A variant of the policy of rebranding organizations was published in [Glushchenko et al. (2019), p. 6-8]. Therefore, the idea of carrying out such a rebranding could well find interested readers.

It is likely that these theses on the problem of rebranding organizations during the crisis were carefully studied. In the future, these theses could receive their own creative development.

Therefore, it cannot be excluded that these theses could become the starting point for the formation of the rebranding process and significant changes in the functioning of the national public administration system? It is known that in the future such changes were formulated in the form of a reform of the management system and approved by holding a referendum in 2020 .

Further development of the methodology of rebranding organizations led to the formation of a detailed theory of rebranding, reflected in a number of publications [Glushchenko (2021); Glushchenko (2020), p. 326-345]. Such a scientific theory of branding and rebranding of organizations can be useful. This is due to the fact that it contains a methodology that can be practically used by various economic entities in the process of their entry into the eighth technological order.

Application for funding of the work: the work was carried out at the expense of the author's own personal funds; there are no external sources of funding for the work.

\section{CONCLUSION}

The article develops a methodology for the formation of a paradigm for the entry of states and other types of organizations into the eighth technological order in the economy and society. The paradigm is understood as a systematic combination of such elements: philosophy; ideology; organizational culture; the policy of the organization's entry into the eighth technological order.

The article examines and substantiates the concept of "technological order". The technological order is understood as the system integration into a single whole of such elements: the technological basis of the organization; production institutions; forms of doing business; methods and management structures in organizations.

The paper proves that the technological order is a large multi-level system. Therefore, the study of technological orders should be carried out within the framework of the theory of large systems, system analysis and synthesis.

The article describes the content of these elements of the paradigm of the organization's entry into a new technological order. The article proves that the beginning of the development of such a paradigm should be a system analysis of the technological order. Based on this system analysis, an image of the future of this technological order can be synthesized.

The article provides examples confirming: the thesis about the need for coordination of technologies and production institutions; the importance of scientific justification of measures, in particular, in the field of global monetary policy; the need for rebranding organizations in the process of changing their external and internal environment, and much more.

The article describes the practical tasks of a number of branch theories of technological orders (geopolitics, politics, sociology, culture, medicine). 
The paper proves that an important part of the process of an organization's entry into the eighth technological order can be the rebranding of organizations.

Application for funding of the work: the work was carried out at the expense of the author's own personal funds; there are no external sources of funding for the work.

\section{REFERENCES}

Aivazov A. (2012). The periodic system of world capitalist development. [Electronic resource] Access mode: http://ajvazov.ru/articles/periodicheskayasistema-mirovogo-kapitalisticheskogo-razvitiya. html, free. Title from the screen. Yaz. rus. (accessed December 2015).

Bobrova O. S., Bobrov I. A. (2015) The role of industrial policy in the modernization of Russia: a view from Japan//In the collection: Foresight "Russia": the design of a new industrial policy. Collection of materials of the St. Petersburg International Economic Congress (SPEC-2015). pp. 307-317.

Brzezinski Z. (2003) The great chessboard. The dominance of America and its geostrategic imperatives. - Moscow: International Relations, p.34.

Feldman P. Ya. (2016) The policy of coordinating interests as a direction of state policy: structural and functional analysis//International relations. No. 3. pp. 272-278.

Glazyev S. Yu. (2016) World economic structures in global economic development//Economics and mathematical methods. Vol. 52. No. 2. pp. 329 Retrieved from https://doi.org/10.2753/PET1061-1991520501

Gluchshenko V. V. (2021) Tasks of system analysis of the sixth technological order / / Kazakhstan Science Journal, , vol. 4 . No. 3 (28), pp. 22-34. Retrieved from https://sciencejournal.press/sj/article/view/244/201 05.03.2021)

(accessed:

Glushchenko I. I. (2009) Formation of innovation policy and strategy of the enterprise. - Moscow: APK and PPRO, - 128 p.

Glushchenko V. V. (2012) Corruptiology: social aspect ( social corruptiology) Moscow: IP Glushchenko Valery Vladimirovich, - 88 p.; ISBN 978-5-90454211-5.

Glushchenko V. V. (2018) Development of the methodology of crisis research and anti-crisis management (to the 10th anniversary of the beginning of the global systemic crisis of 2008) / / Bulletin of Science and Practice. Vol. 4. No. 9. pp. 333-354.

Glushchenko V. V. (2018) General theory of human rights (science of the rights of individuals and legal entities) / / Bulletin of Science and practice. Vol. 4. No. 8. pp. 303-339.

Glushchenko V. V. (2021) Implementation of a strategic project to improve the position of a technical university in the world rankings / / Modern scientific research and innovations. No. 6 [Electronic resource]. Retrieved from https://web.snauka.ru/issues/2021/06/95842 (accessed: 23.06.2021).

Glushchenko V. V. (2008) Introduction to crisis management. Financial crisis. Anticrisis management. - Moscow: IP Glushchenko V. V., p. 23; ISBN 978-59901406-2-2;

Glushchenko V. V. Krisologiya-(2014): methodological aspects of global anti-crisis management// Russia: trends and prospects of development, Yearbook, Issue 10, Part I; INION RAS, 2014, pp. 250-255. 
Glushchenko V. V. (2020) Neurogeopoliticology and methodological aspects of strategic management of geopolitical risk//Modern scientific research and innovation. No. 4 (108). p. 34. Retrieved from http:/ / web. snauka. $\mathrm{ru} /$ issues/2020/04/91886

Glushchenko V. V. (2008) Political science: a system-management approach. - M.: IP Glushchenko V. V., -160 p.

Glushchenko V. V. (1999) Risk management. Insurance. - Zheleznodorozhny, M. O., LLP SPC "Wings", p. 46

Glushchenko V. V. (2006) Risks of innovation and investment activity in the conditions of globalization. - Zheleznodorozhny, Moscow region: LLC SPC "Krylia", p.200

Glushchenko V. V. (2020) Scientific theory of brands, branding and rebranding (brandology) and the tasks of its practical use in organizations // Bulletin of Science and Practice. Vol. 6. No. 5. pp. 326-345. Retrieved from https://doi.org/10.33619/2414-2948/54/43

Glushchenko V. V. (2009) Technological theory of post-industrial money / / Finance and Credit, No. 46 (382), pp. 7-16.

Glushchenko V. V. (2007) The State as a geopolitical public corporation in the postindustrial global world// National Interests: Priorities and Security No. $6(15)$.

Glushchenko V.V. (2020) The paradigm of intellectual management of the formation of the sixth technological order in the economy// The scientific heritage, vol. 4, No. 45 (2020), p. 54-63.

Glushchenko V. V. (2012) The science of money: the technological theory of money. - Moscow: IP Glushchenko Valery Vladimirovich, - 88 p., ISBN 978-5904542-12-2

Glushchenko V. V. (2020) Tools for the development of a neurotechnological platform in mechanical engineering of the sixth technological order/ / Kazakhstan Science Journal, No. 1 (14), pp. 44-63. Retrieved from https://sciencejournal.press/sj/article/view/138/123

Glushchenko V. V., Glushchenko I. I. (2016) The essence of the monetary innovation multiplier in the economy/ / / / Bulletin of Science and practice. No. 3. pp. 77-88. [Electronic resource].

Glushchenko V. V., Goncharov I. A., Omelchenko V. D. (2019) The policy of rebranding of economic entities / / Scientific achievements: theory, methodology, practice. Collection of scientific papers based on the materials of the VI International Scientific and Practical Conference.- Anapa (28.03.2019), Innova Research Center, p. 6-8.

Glushchenko V. V., (2020) The theory of technological orders. - M.: Glushchenko Valery Vladimirovich, p. 12-20

Glushchenko V.V. (2021) Control Mechanism of Increasing Economic Efficiency of Corporate Re-branding. In: Solovev D. B., Savaley V. V., Bekker A. T., Petukhov V. I. (eds) Proceeding of the International Science and Technology Conference "FarEastCon 2020". Smart Innovation, Systems and Technologies, vol 227. Springer, Singapore. Retrieved from https://doi.org/10.1007/978-981-16-0953-4_123

Glushchenko, V. V. (2021). Management System for the Development of Industrial Social Relations of a New Technological Order. International Journal of Scientific Advances (IJSCIA), Volume 2| Issue 4: May-Jun 2021, Pages 554563, Retrieved from https://www.ijscia.com/wp- 
content/uploads/2021/07/Volume2-Issue4-Jul-Sep-No.128-554-563.pdf. (accessed 29.07.2021).

Glushchenko, V. V. (2021). Strategic planning of organizations ' transition to the sixth technological order in the national economy// International Journal of Engineering Science Technologies, 5(1), pp. 30-38. Retrieved from https://doi.org/10.29121/ijoest.v5.i1.2021.159.

Glushchenko, V. V. (2021). The mission and essence of the theory of technological orders// International Journal of Engineering Science Technologies, 5(4), 65-82. Retrieved from https://doi.org/10.29121/ijoest.v5.i4.2021.205

Knyshova E. N. (2009) Marketing. studies. posob-M.: ID "Forum": INFRA-M, -282 s

Kolchinsky E. I. N. I. Vavilov And T. D. (2018) Lysenko in the space of historical and scientific discussions//Nature. No. 1 (1229). pp. 3-14.

Komkov N. I. (2016) Building a model of economic development based on the coordination of the innovation sphere and the model of development companies//In the book: Managing the development of large-scale mlsd systems '. Materials of the Ninth International Conference: in 2 volumes. Under the general editorship of S. N. Vasiliev, A. D. Tsvirkun. 2016. pp. 6677.

Mesarovich M., Mako D., Takahara I. (1973) Theory of hierarchical multilevel systems. - Moscow: Mir, p.12-17

Nanotechnologies as a key factor of a new technological structure in the economy / Edited by S. Yu. Glazyev and V. V. Kharitonov (2009)- Moscow: Trovant, - $304 \mathrm{p}$.

Orusova O. V., Eliseeva T. S. (2015) Development of a strategy for Russia's transition to the sixth technological order//In the collection: The development of modern Russia: problems of reproduction and creation/Collection of scientific papers. Edited by R. M. Nureyev, M. L. Alpidovskaya. pp. 82-89.

Parmy Olson (2010). Zoellick Suggests Return To Gold Standard//FORBES; Nov 8,

Pavlova A. V. (2016) Regional policy as a mechanism for implementing the innovation policy of France//In the collection: Social communications and the evolution of societies. Materials of the V International Scientific and Practical Conference. Edited by I. A. Waldman; Novosibirsk State Technical University. pp. 353-358.

Pobol A. I. (2017) Conceptual model of factors driving the innovative it cluster development//Journal of the Belarusian State University. Economy.. No. 1. pp. 39-45. Retrieved from http://elib.bsu.by/handle/123456789/183127

Vertakova Yu. V. (2015) Cluster policy and tools for structural transformations of regional socio-economic systems//In the collection: Cluster initiatives in the formation of a progressive structure of the national economy. collection of scientific papers of the International scientific and Practical Conference: in 2 volumes. pp. 11-14.

Zagidullina G. M., Sobolev E. A., Krylovsky A. B. (2015) Forecasting the structure of the innovative sixth technological order and analyzing the priorities of current industrial development//Proceedings of the Kazan State University of Architecture and Civil Engineering. No. 1 (31). pp. 182-189. 